\title{
Role of Educational Technology in Public and Private Institutes at Secondary School Level in Karak District, Pakistan
}

\author{
Qaiser Suleman \\ M.Phil (Education) Scholar, Institute of Education \& Research, Kohat University of Science \\ \& Technology, Khyber Pakhtunkhwa, (Pakistan) \\ Email: Look_for_reality@yahoo.com \\ Dr. Ishtiaq Hussain \\ Assistant Professor, Institute of Education \& Research, Kohat University of Science \& \\ Technology, Khyber Pakhtunkhwa, (Pakistan) \\ Email: dr.ishtiaqkust@gmail.com
}

\begin{abstract}
Zaitoon Akhtar
M.Phil (Education) Scholar, Institute of Education \& Research, Kohat University of Science \& Technology, Khyber Pakhtunkhwa, (Pakistan)
\end{abstract}

Accepted: July 24, $2012 \quad$ Published: September 03, 2012

Doi:10.5296/ijld.v2i5.2337 URL: http://dx.doi.org/10.5296/ijld.v2i5.2337

\begin{abstract}
The purpose of the study was to explore the role of educational technology in public and private institutes. All the heads, teachers and students in public and private secondary schools in district Karak, Pakistan constituted the population of the study. In order to ensure adequate representation of the population, 60 heads, 180 teachers and 600 students serving and studying in public and private sectors at secondary school level in Karak District were selected through simple random sampling technique. The study was delimited to only 20 male public and 20 male private secondary schools. The study was descriptive in nature and a self-developed questionnaire was used for the collection of data. The researchers personally visited the respective sample and distributed the questionnaires among the participants. In this way data was collected. Percentage, mean, standard deviation and t-test were used for the statistical analysis of the data. After analysis of the data, it was concluded that educational technologies are not available in both sectors. Some technologies were available in minor amount but these technologies were not used in both public and private sectors. Based on findings, it was recommended that availability of educational technology should be ensured on priority basis. A special supervisory staff should be appointed to check the utilization of the educational technology in public and private secondary institutions.
\end{abstract}

Keywords: Role, Educational Technology, Public Institutes, Private Institutes, Secondary 
School Level

\section{Introduction}

Education means to bring about desirable changes in the behavior of an individual according to the needs and requirements of its concerned society. If a teacher succeeds in framing a sound base and making the entire concept clear to a student then it is justified to say that in future the student will be able cope with complex and difficult things easily. Therefore, it depends upon quality education and effective instructional process. Educational technologies play a crucial and significant role in this connection. Educational Technologies are those materials, procedures, ideas, organizations, devices, instruments or machines that facilitate instructional process and makes it more effective, interesting, successful, and unforgettable (Suleman, 2011). The word educational technology was familiarized in 1967 when National Council for Educational Technology was established in United Kingdom. The United Kingdom Association for programmed learning immediately added "Educational technology" to its heading in 1968. In the USA it was the department of Audio-Visual Instruction of National Education Association for Educational Commission and technology in 1970. The term "System" appeared quite regularly in the early writings on Educational Technology. But it did not become extensively adopted immediately as a central conceptual framework. Educational Technology is permanently established now as a field of study. Instructional development, educational communication and educational resources are the names, which explain the field (Venkataiah, 1996). Educational technology is complex, comprehensive and integrated process, which is involved in many things like, people, ideas, procedures, devices and organizations which are design to evaluate problems. It is also composed of other different processes like, devising, implementing, evaluating and managing solutions to those problems that involve in all aspects of human learning.

The current paper was specially designed to compare the role of educational technology in private and public sectors at secondary level in Karak District. The study is beneficial for the teachers teaching in private and public institutions because it has explored the usefulness of technology in teaching learning process and therefore, it is expected that teachers will utilize the available technologies for the instructional process. It is also helpful for the government to asses the current status of educational technology regarding availability and usability of technologies in private and public institutions at secondary level and it is expected that government will ensure the availability of educational technology in public and private institutions.

\section{Review of Related Literature}

Educational technology is complex, comprehensive and integrated process, which is involved in many things like, people, ideas, procedures, devices and organizations which are design to evaluate problems. It is also composed of other different processes like, devising, implementing, evaluating and managing solutions to those problems that involve in all aspects of human learning (AECT, 1977). Educational technology is the combination of those instructional, developmental, managerial and other technologies which are used particularly 
to find out the solution of educational problems (Tomei, 2002). It is a system in education which is the mixture of variety of things like, machines, media, materials, men and methods working together to attain and fulfill specific educational objectives (Sharma \& Sharma, 2006). Educational Technology is the systematic use of scientific or other organized knowledge to practical tasks (Galbraith, 1967). Educational Technology is an area of study, which facilitate and improve human learning through systematic identification, organization, development and utilization of learning resources and through the management of processes, but it is not limited to these processes but it also consists of those people who performs these processes (Sharma and Sharma, 2006).

Educational technology refers to the utilization of technology to develop and improve the education system. It is a systematic process used to design instruction or training for the improvement of the performance. Sometimes educational technology is also known as instructional technology or learning technology (Wikipedia Educational Technology). Educational Technology is a systematic process used to design instruction or training in order to improve the performance (Encyclopedia of Educational Technology). Educational technology means to utilize a variety of techniques and procedures to design a learning experience systematically (Venkataiah, 1996). It is reality that educational technology plays a helping role to explain complicated and difficult concepts, to stimulate individual and group activities, to promote a collective critical awareness, to change the attitudes, to implement a new structure or organization of definite subjects and to encourage originality and creativeness (Mohanty, 1992). Therefore, it is concluded that educatioal technolgies composed of all those things which are involved in facilitatitng instructional process and make it more effective, successful, interested and producitve.

Successful integration of technology mostly depends upon its availability. Research studies have shown that non-availability of technologies is the main barrier in technology integration in classroom. Mumtaz (2000) concluded that non-availability of technology was the main factor reducing the utilization of technology by the teachers in their instructional process. Research studies show that due to non-availability and inaccessibility of instructional resources in school, the students and teachers do not use them (Veen, 1993; Byard, 1995, Wild, 1996). That is why it can be rightly said that availability of educational technology is the fundamental and crucial factor for the successful integration of educational technologies during instructional process. Hope (1997) stated repeatedly that exploitation of technology in an environment needs its availability to be ensured first. He further stated that accessibility to hardware is the obstruction in the way of successful integration of technology.

Teachers play a vital and crucial role in integrating technology in teaching learning process and therefore, it is imperative for teachers to have experiences and skills to use technology effectively. Smarkola (2008) noted that those teachers are very important who are competent and expert in utilizing and managing educational technology. The student teachers should be trained for the effective utilization of educational technology in the initial teacher education programme. Ring staff and Kelley (2002) concluded from research studies that 
teachers who receive formal training for the effective utilization of technology for instructional process, they have succeeded to bring remarkable and significant improvements in the student's achievement.

\section{Characteristics of Educational Technology}

According to Sharma and Sharma (2006), characteristics of the educational technology are explained as under:

1. It uses scientific principles to the problems of education.

2. It emphasizes on the development of the methods, procedures and techniques for the successful and effective instructional process.

3. It puts stress on the designing and measuring instruments and tools for the assessment of instructional outcomes.

4. It makes the instructional process more facilitated, productive and effective by media, methods, and techniques and by controlling classroom environment.

5. It involves in three aspects in education e.g. input, teaching learning process and output.

6. It consists of applications of electronic media in education and systems approach.

7. It plays a crucial role as medium of communication.

8. It is a broad and comprehensive term. It is composed of different terms e.g., teaching technology, instructional technology, micro teaching, programmed learning and system analysis etc.

9. It is not the synonyms of the Audio-Visual Aids in education but it is more broad and comprehensive term.

\section{Objectives of Educational Technology}

Educational technology has played a fundamental and crucial role in the education system. It has influenced and enhanced the teaching learning process. However, the main objectives of the educational technology in education are explained as under:

1. It helps in improving teaching learning process and makes it more effective and purposive.

2. The standard of education has been collapsed due to mass education. The application of educational technology can improve and preserve the standard of education by the use of teaching aids and other instructional materials.

3. It plays an effective role in improving the distance education or correspondence education by the utilization of technologies i.e. television, radio, tape record and other programmed instructions.

4. Teacher training institutions have failed in producing effective and competent teachers. Effective and skillful teachers can be produced by the use of educational technologies in teacher training institutions.

5. Through System Analysis, administrative problems in education can be solved logically and scientifically.

6. Educational researches have no effects on the contemporary educational problems because these researches have theoretical in nature. Educational technology has 
played an important role in solving classroom teaching and training problems practically and experimentally.

7. It helps in understanding the nature and structure of instructional process. To attain various educational objectives, teaching models can be developed.

8. The key problem in instructional process is to cope with individual differences in effective way. The educational technology has developed new innovative practices and strategies to ensure the solution of these problems.

9. It also helps in building up educational theories for teaching and instruction and makes scientific foundation to education (Sharma and Sharma, 2006).

\section{Usefulness of Educational Technology}

According to Aggarwal (1995), educational technology has added much to the effectiveness of the teaching learning process. The important contributions of educational technology to teaching learning process are explained as under:

1. It helps in individualizing instruction by enabling individuals to use self-instructional programmes.

2. It plays a vital role in the enhancement of the instructional process. It enables us to use various enriched and motivating programmes through different media.

3. It helps in using a variety of useful programmes designed and developed for a massive number of students. These programmes are used through television, computers etc.

4. It has played a fundamental and crucial role in equalizing educational opportunities without taking into consideration the social, economic and geographical status of the students.

5. The learners in service personnel and vocational works are kept in touch with the latest material through television lessons and self-instructional programmed material, which is sent to them.

\section{Statement of the Problem}

The study under investigation was specially designed to know the role of educational technology in public and private secondary institutions. Therefore, the title of the problem was designed as "Role of Educational Technology in Public and Private Institutes at Secondary School Level in Karak District, Pakistan”.

\section{Objectives of the Study}

The objectives of the study were:

(a) to compare the availability of educational technology in public and private institutions at secondary level;

(b) to compare the usability of educational technology in public and private institutions at secondary level and

(c) to find out the significance of educational technology in public and private institutions at secondary level. 
Research Methodology

\section{Participants}

All the heads, teachers and students in public and private institutions at secondary school level in Karak District constituted the population of the study. In order to ensure adequate sample, 60 heads, 180 secondary school teachers and 600 students serving and studying in public and private institutions at secondary school level in District Karak were selected randomly. The detail of the sample is given as under:

Table 01: Showing the Size of Sample

\begin{tabular}{cccccccc}
\hline \multirow{2}{*}{ Sectors } & \multicolumn{2}{c}{ No. of Selected Schools } & & & & \\
\cline { 2 - 3 } & Urban & Rural & Heads & Teachers & Students & Total \\
\hline Public & 10 & 20 & 30 & 90 & 300 & $\mathbf{4 2 0}$ \\
Private & 10 & 20 & 30 & 90 & 300 & $\mathbf{4 2 0}$ \\
\hline Total & $\mathbf{2 0}$ & $\mathbf{4 0}$ & $\mathbf{6 0}$ & $\mathbf{1 8 0}$ & $\mathbf{6 0 0}$ & $\mathbf{8 4 0}$ \\
\hline
\end{tabular}

\section{Delimitations of the Study}

The study was delimited to 20 male public and 20 private secondary schools in Karak District. Educational technology is broad subject and it was not possible to cover all the educational technology in this research study. Therefore the researchers concentrated only on those technologies which are commonly used in our institutions. These were; computers, multimedia, overhead projectors, educational televisions, radios, DVD players, white boards, charts, models, educational software and videos.

\section{Research Instrument}

The study was descriptive in nature therefore, the researchers decided to develop questionnaire for the collection of data. A single questionnaire was developed for the whole sample.

\section{Pilot Testing}

Validation and authentication of the research instrument is important to achieve exact and precise results. For this purpose, pilot testing was conducted to eliminate the weaknesses, misconceptions and ambiguities of the questions in the questionnaire. So after pilot testing, it was revised and then its final version was developed in the light of suggestions given by the experts.

\section{Validity and Reliability}

It is essential to ensure the trustworthiness of the research and its findings by addressing the issues of validity and reliability. Validity is the degree to which study assess the same concept that the researcher is trying to measure. Validity of the questionnaire was checked by three experts. Reliability is the degree of consistency that an instrument or data collection procedure demonstrates, while validity is the quality of the collection procedure of the data that enables it to measure what it intends to measure. Cronbach's alpha reliability test was 


\section{Macrothink}

International Journal of Learning \& Development

ISSN 2164-4063

2012, Vol. 2, No. 5

used to calculate the reliability of questionnaire. The reliability coefficient was found to be 0.86 for the questionnaire. The following formula was used:

$$
\alpha=\frac{N \cdot \bar{C}}{\bar{V}+(N-1) \cdot \bar{C}}
$$

Where

$$
\begin{aligned}
& \mathrm{N}=\text { Total number of respondents } \\
& \bar{C}=\text { Average inter-item covariance } \\
& \bar{V}=\text { Average variance }
\end{aligned}
$$

\section{Collection of Data}

The researchers personally visited the respective sample public and private secondary institutions and distributed the questionnaires among the heads, teachers and students. Firstly, difficult items were explained and then they were asked to give appropriate responses without any hesitation and free of bias. In this way data was collected.

\section{Data Analysis}

After the collection of data, it was organized, tabulated, analyzed and interpreted. Simple percentage, chi square, mean, standard deviation and t-test were used for the statistical analysis of the data. The following formulae were used:

\section{For Yes/No Responses}

For Yes/No responses, the following system and formula was used:

\begin{tabular}{cccccc}
\hline Institutions & Yes & No & Total & $\chi^{2}$ & p-value \\
\hline Public & A & B & A+B & & \\
Private & C & D & C + D & & \\
\hline Total & A+C & B + D & A+B $+\mathbf{C}+\mathbf{D}=\mathbf{N}$ & \\
\hline
\end{tabular}

$$
X^{2}=\frac{N(A D-B C)^{2}}{(A+B)(C+D)(A+C)(B+D)}
$$

Where

$\mathrm{A}$ and $\mathrm{C}$ are the number of responses under Yes

$\mathrm{B}$ and $\mathrm{D}$ are the number of responses under No

$\mathrm{N}$ is the total number of frequencies/responses

For the Analysis of Usability and Usefulness of Educational Technology on Five Point Likert's Scale:

For the analysis of usability and usefulness of educational technology in teaching learning process was analyzed by the help of the following formula:

$$
\mathrm{X}^{2}=\sum \frac{\left[\left(f_{o}-f_{e}\right)^{2}\right]}{f_{e}}
$$


Where

$\mathrm{X}^{2}=$ Chi-square

$\sum=$ Sum of

$\mathbf{f}_{\mathbf{0}}=$ Frequency of occurrence of observed

$\mathbf{f}_{\mathbf{e}}=$ Expected frequency

\section{Analysis and Interpretation of Data}

The study was descriptive in nature therefore, the researchers decided to develop questionnaire for the collection of data. A single self developed questionnaire was used for the whole sample. The researchers personally visited to the respective sample and distributed the questionnaires among the heads, teachers and students in public and private secondary schools. In this way data was collected. After the collection of data, it was organized, tabulated and analyzed. The researchers decided to apply chi-square for the statistical treatment of the data. Therefore, chi square was applied to compare the data. The whole process of analysis is explained as under:

\section{Analysis of the Availability of Educational Technology}

Table 01: Responses of the respondents about the Availability of Computers

\begin{tabular}{|c|c|c|c|c|c|}
\hline Institutions & Yes & No & $\mathbf{N}$ & $\chi^{2}$ & p-value \\
\hline \multirow{2}{*}{ Public } & 037 & 383 & \multirow{2}{*}{420} & \multirow{5}{*}{$245.71 *$} & \multirow{4}{*}{0.000} \\
\hline & $08.8 \%$ & $91.2 \%$ & & & \\
\hline \multirow{2}{*}{ Private } & 253 & 167 & \multirow{2}{*}{420} & & \\
\hline & $60.2 \%$ & $39.8 \%$ & & & \\
\hline Total & 204 & 636 & 840 & & \\
\hline Significant (p & & df $=1$ & e val & at 0.05 & 03.841 \\
\hline
\end{tabular}

Table 1 depicts that the calculated value of $\chi^{2}$ was found to be 245.71 which is statistically significant $(\mathrm{p}<0.05)$ because it is greater than the table value of $\chi^{2}$ at 0.05 level. It shows that computers were available in private institutions to some extent but not available in the public sector institutions.

Table 02: Responses of the respondents about the availability of Multimedia

\begin{tabular}{|c|c|c|c|c|c|}
\hline Institutions & Yes & No & $\mathbf{N}$ & $\chi^{2}$ & p-value \\
\hline Public & $\begin{array}{c}022 \\
05.2 \%\end{array}$ & $\begin{array}{c}398 \\
94.8 \%\end{array}$ & 420 & & \\
\hline Private & $\begin{array}{c}013 \\
03.1 \%\end{array}$ & $\begin{array}{c}407 \\
96.9 \%\end{array}$ & 420 & 02.42 & 0.120 \\
\hline Total & 035 & 805 & 840 & & \\
\hline
\end{tabular}

Table 2 illustrates that the calculated value of $\chi^{2}$ was found to be 02.42 which is statistically non-significant $(p>0.05)$ because it is less than the table value of $\chi^{2}$ at 0.05 level. It 
unambiguously indicates that multimedia was not available in both public and private sectors.

Table 03: Responses of the respondents about the availability of Overhead Projectors

\begin{tabular}{|c|c|c|c|c|c|}
\hline Institutions & Yes & No & $\mathbf{N}$ & $\chi^{2}$ & p-value \\
\hline Public & $\begin{array}{c}029 \\
06.9 \%\end{array}$ & $\begin{array}{c}391 \\
93.1 \%\end{array}$ & 420 & & \\
\hline Private & $\begin{array}{c}032 \\
07.6 \% \\
\end{array}$ & $\begin{array}{c}388 \\
92.4 \% \\
\end{array}$ & 420 & 0.159 & 0.690 \\
\hline Total & 144 & 696 & 840 & & \\
\hline
\end{tabular}

Table 03 shows that the calculated value of $\chi^{2}$ was found to be 0.159 which is statistically non-significant ( $p>0.05$ ) because it is less than the table value of $\chi^{2}$ at 0.05 level. It clearly indicates that overhead projectors were not available both sectors.

Table 04: Responses of the respondents about the availability of Educational Televisions

\begin{tabular}{|c|c|c|c|c|c|}
\hline Institutions & Yes & No & $\mathbf{N}$ & $\chi^{2}$ & p-value \\
\hline \multirow{2}{*}{ Public } & 024 & 396 & \multirow{2}{*}{420} & \multirow{5}{*}{00.90} & \multirow{5}{*}{0.342} \\
\hline & $05.7 \%$ & $94.3 \%$ & & & \\
\hline \multirow{2}{*}{ Private } & 018 & 402 & \multirow{2}{*}{420} & & \\
\hline & $04.3 \%$ & $95.7 \%$ & & & \\
\hline Total & 042 & 798 & 840 & & \\
\hline Non-Significa & $0.05)$ & df $=$ & table $v$ & $20+0$ & $=03.841$ \\
\hline
\end{tabular}

Table 04 depicts that the calculated value of $\chi^{2}$ was found to be 00.90 which is statistically non-significant ( $p>0.05$ ) because it is less than the table value of $\chi^{2}$ at 0.05 level. It plainly shows that educational televisions were not available both in public and private institutions.

Table 05: Responses of the respondents about the availability of Radios

\begin{tabular}{|c|c|c|c|c|c|}
\hline Institutions & Yes & No & $\mathbf{N}$ & $\chi^{2}$ & p-value \\
\hline Public & $\begin{array}{c}022 \\
05.2 \%\end{array}$ & $\begin{array}{c}398 \\
94.8 \%\end{array}$ & 420 & & \\
\hline Private & $\begin{array}{c}015 \\
03.8 \% \\
\end{array}$ & $\begin{array}{r}405 \\
96.2 \\
\end{array}$ & 420 & 01.39 & 0.239 \\
\hline Total & 037 & 803 & 840 & & \\
\hline
\end{tabular}

Table 05 illustrates that the calculated value of $\chi^{2}$ was found to be 01.39 which is statistically non-significant $(p>0.05)$ because it is less than the table value of $\chi^{2}$ at 0.05 level. It clearly indicates that radios were not available in both public and private institutions. 
Table 06: Responses of the respondents about the availability of Whiteboards

\begin{tabular}{cccccc}
\hline Institutions & Yes & No & $\mathbf{N}$ & $\chi^{2}$ & p-value \\
\hline \multirow{2}{*}{ Public } & 037 & 383 & $\mathbf{4 2 0}$ & & \\
& $08.8 \%$ & $91.2 \%$ & & \multirow{3}{*}{ 338.24* } & $\mathbf{0 . 0 0 0}$ \\
Private & 298 & 122 & $\mathbf{4 2 0}$ & & \\
\cline { 1 - 3 } Total & $71.0 \%$ & $29.0 \%$ & $\mathbf{5 4 0}$ & & \\
\hline
\end{tabular}

*Significant $(p=.000<0.05) \quad$ df $=1 \quad$ table value of $\chi^{2}$ at 0.05 level $=03.841$

Table 6 shows that the calculated value of $\chi^{2}$ was found to be 338.24 which is statistically significant $(p<0.05)$ because it is greater than the table value of $\chi^{2}$ at 0.05 level. It indicates that whiteboards were available in private institutions but not available in public institutions.

Table 07: Responses of the respondents about the availability of DVD Players

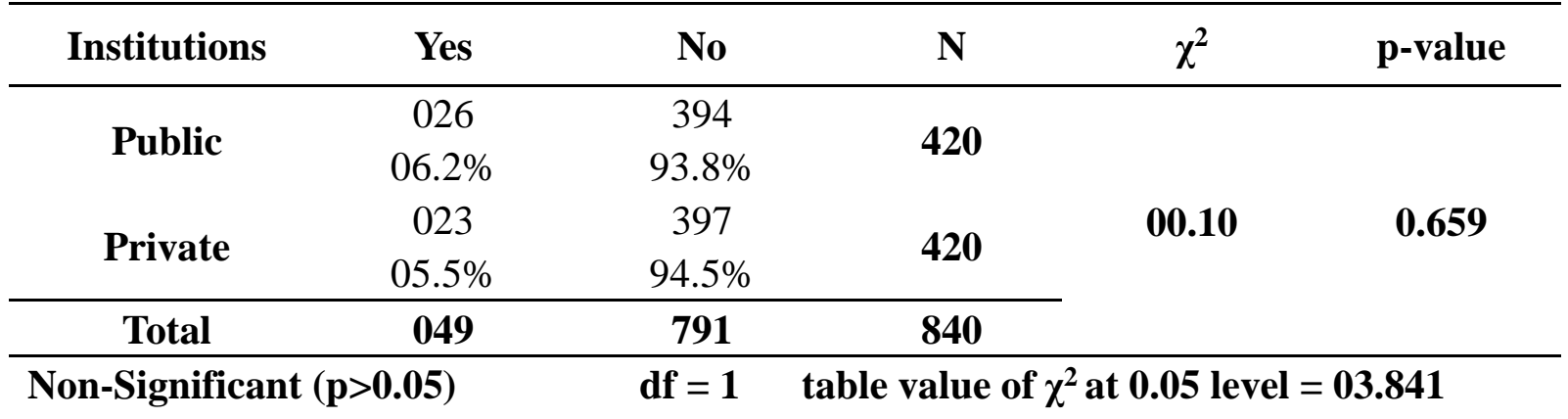

Table 7 depicts that the calculated value of $\chi^{2}$ was found to be 00.10 which is statistically non-significant ( $p>0.05$ ) because it is less than the table value of $\chi^{2}$ at 0.05 level. It clearly depicts that DVD players were not available in both sectors at all.

Table 08: Responses of the respondents about the availability of Charts

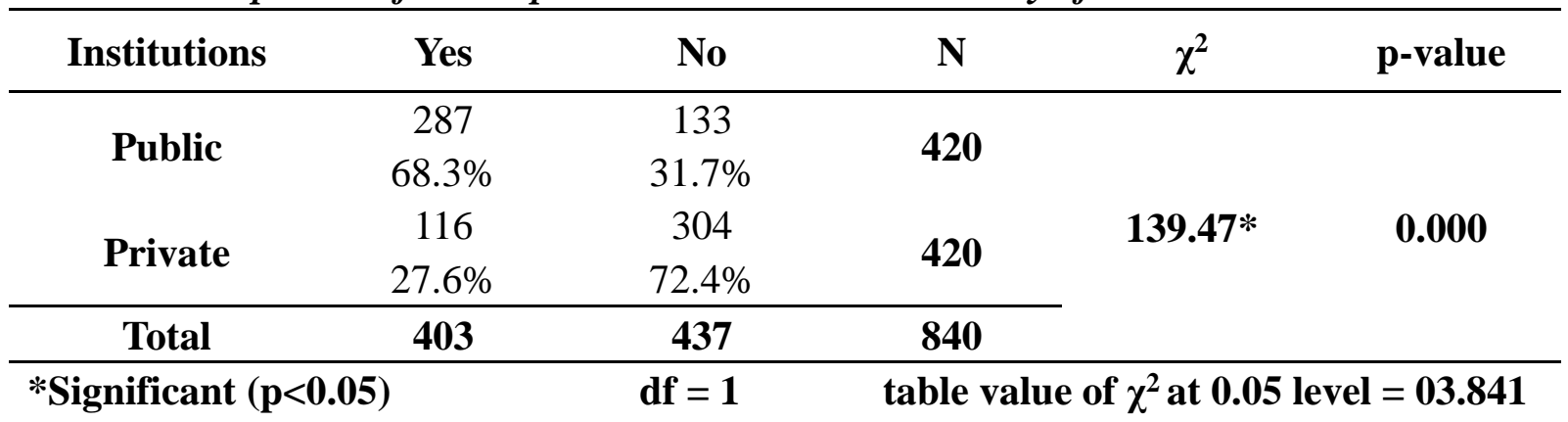

Table 8 indicates that the calculated value of $\chi^{2}$ was found to be 139.47 which is statistically significant $(p<0.05)$ because it is greater than the table value of $\chi^{2}$ at 0.05 level. It clearly shows that charts were available in public sector but not available in private sector.

Table 09: Responses of the respondents about the availability of Models

\begin{tabular}{cccccc}
\hline Institutions & Yes & No & N & $\chi^{2}$ & p-value \\
\hline
\end{tabular}




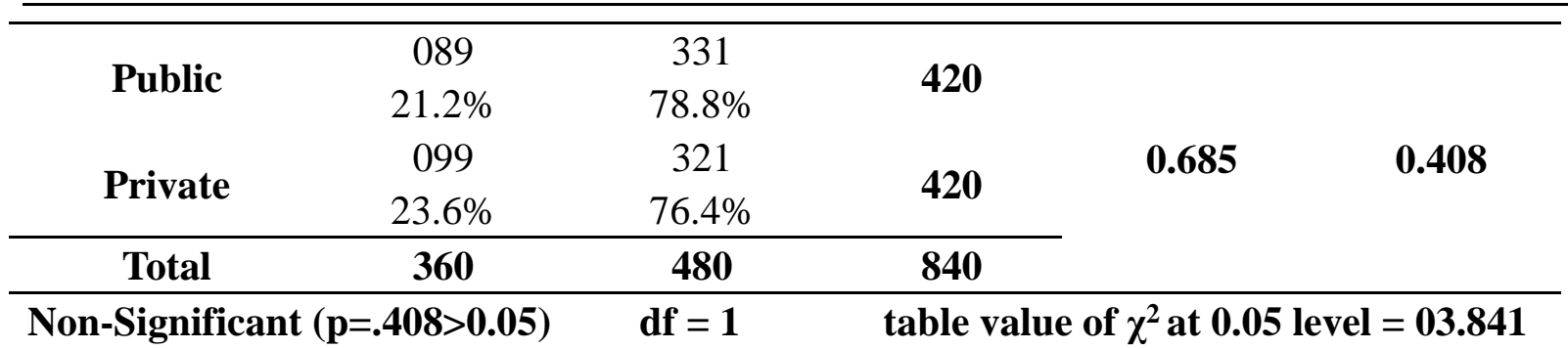

Table 09 reflects that the calculated value of $\chi^{2}$ was found to be 0.685 which is statistically non-significant $(p>0.05)$ because it is less than the table value of $\chi^{2}$ at 0.05 level. It ambiguously shows that models were not available in both public and private institutions.

Table 10: Responses of the respondents about the availability of Educational Software and Videos

\begin{tabular}{|c|c|c|c|c|c|}
\hline Institutions & Yes & No & $\mathbf{N}$ & $\chi^{2}$ & p-value \\
\hline \multirow{2}{*}{ Public } & 047 & 373 & \multirow{2}{*}{420} & \multirow{5}{*}{$190.35 *$} & \multirow{5}{*}{0.000} \\
\hline & $11.2 \%$ & $88.8 \%$ & & & \\
\hline \multirow{2}{*}{ Private } & 236 & 184 & \multirow{2}{*}{420} & & \\
\hline & $56.2 \%$ & $43.8 \%$ & & & \\
\hline Total & 283 & 557 & 840 & & \\
\hline Significant (p & $<0.05)$ & df $=1$ & ble va & 2 at 0.05 & $=03.841$ \\
\hline
\end{tabular}

Table 10 depicts that the calculated value of $\chi^{2}$ was found to be 190.35 which is statistically significant $(\mathrm{p}<0.05)$ because it is greater than the table value of $\chi^{2}$ at 0.05 level. It shows that educational software and videos were available in private institutions but not available in public institutions.

\section{Analysis of the Usability of Educational Technology}

Table 11: Responses of the respondents about the use of Computers

\begin{tabular}{|c|c|c|c|c|c|c|}
\hline Institution & $\mathbf{N}$ & Mean & SD & SE & t-value & p-value \\
\hline Public & 420 & 2.2 & 0.75 & \multirow{2}{*}{0.07} & \multirow{2}{*}{$19.52 *$} & \multirow{2}{*}{0.000} \\
\hline Private & 420 & 3.5 & 1.14 & & & \\
\hline Key: & \multicolumn{2}{|c|}{$\begin{array}{l}N=\text { No. } \text { of Respondents } \\
S E=\text { Standard Error }\end{array}$} & & \multicolumn{3}{|c|}{$\begin{array}{l}\text { SD= Standard Deviation } \\
\boldsymbol{p}=\text { probability }\end{array}$} \\
\hline *Significant (p & & $f=838$ & & value & at $0.05 \mathrm{l}$ & $=1.963$ \\
\hline
\end{tabular}

Table 11 reflects that the calculated value of $\mathrm{t}$ was found to be 19.52 which is statistically significant $(p>0.05)$ because it is greater than the table value of $t$ at 0.05 level. The mean scores show that computers were used in private institutions to some extent but not used in public institutions. 
Table 12: Responses of the respondents about the use of Multimedia

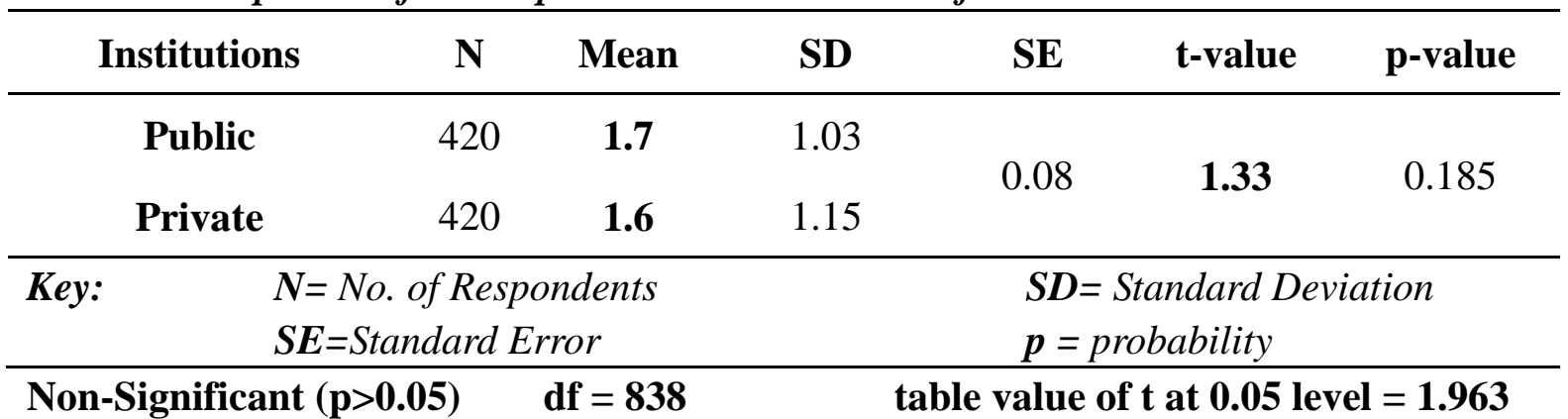

Table 12 indicates that the calculated value of $t$ was found to be 1.33 which is statistically non-significant ( $p>0.05$ ) because it is less than the table value of $t$ at 0.05 level. It shows that multimedia was not used in both public and private institutions at all.

Table 13: Responses of the respondents about the use of Overhead Projectors

\begin{tabular}{|c|c|c|c|c|c|c|c|}
\hline & & $\mathbf{N}$ & Mean & SD & SE & t-value & p-value \\
\hline & & 420 & 1.5 & 1.17 & \multirow{2}{*}{0.08} & \multirow{2}{*}{1.26} & \multirow{2}{*}{0.210} \\
\hline & & 420 & 1.6 & 1.14 & & & \\
\hline Key: & \multicolumn{3}{|c|}{$\begin{array}{l}N=\text { No. of Respondents } \\
\text { SE=Standard Error }\end{array}$} & & \multicolumn{3}{|c|}{$\begin{array}{l}\boldsymbol{S D}=\text { Standard Deviation } \\
\boldsymbol{p}=\text { probability }\end{array}$} \\
\hline
\end{tabular}

Table 13 depicts that the calculated value of $\mathrm{t}$ was found to be 1.26 which is statistically non-significant because it is less than the table value of tat 0.05 level. The mean scores show that overhead projectors were not used in both public and private institutions at all.

Table 14: Responses of the respondents about the use of Educational Televisions

\begin{tabular}{ccccccc}
\hline Institutions & N & Mean & SD & SE & t-value & p-value \\
\hline Public & 420 & $\mathbf{1 . 2}$ & 0.68 & & & \\
Private & 420 & $\mathbf{1 . 3}$ & 1.02 & 0.06 & $\mathbf{1 . 6 7}$ & 0.095 \\
\hline
\end{tabular}

\begin{tabular}{lcc}
\hline Key: & $\boldsymbol{N}=$ No. of Respondents & $\boldsymbol{S} \boldsymbol{D}=$ Standard Deviation \\
& $\boldsymbol{S E}=$ Standard Error & $\boldsymbol{p}=$ probability \\
\hline Non-Significant $(\mathbf{p}>\mathbf{0 . 0 5}) \quad \mathbf{d f}=\mathbf{8 3 8}$ & table value of $\mathbf{t}$ at $\mathbf{0 . 0 5}$ level $=\mathbf{1 . 9 6 3}$
\end{tabular}

Table 14 shows that the calculated value of $\mathrm{t}$ was found to be 1.67 which is statistically non-significant because it is less than the table value of $t$ at 0.05 level. The mean scores show that educational televisions were not used in both public and private institutions at all.

Table 15: Responses of the respondents about the use of Radios

$\begin{array}{lllllll}\text { Institutions } & N & \text { Mean } & \text { SD } & \text { SE } & \text { t-value } & \text { p-value }\end{array}$




\begin{tabular}{|c|c|c|c|c|c|c|c|}
\hline & Public & 420 & 1.6 & 1.15 & \multirow{2}{*}{0.08} & \multirow{2}{*}{$2.67 *$} & \multirow{2}{*}{0.008} \\
\hline & Private & 420 & 1.4 & 1.02 & & & \\
\hline Key: & \multicolumn{3}{|c|}{$\begin{array}{l}\boldsymbol{N}=\text { No. } \text { of Respondents } \\
\mathbf{S E}=\text { Standard Error }\end{array}$} & & \multicolumn{3}{|c|}{$\begin{array}{l}S D=\text { Standard Deviation } \\
p=\text { probability }\end{array}$} \\
\hline
\end{tabular}

Table 15 reflects that the calculated value of $\mathrm{t}$ was found to be 02.67 which is statistically significant because it is greater than the table value of $t$ at 0.05 level. The mean score values show radios were not used in both public and private institutions at all.

Table 16: Responses of the respondents about the use of Whiteboards

\begin{tabular}{|c|c|c|c|c|c|c|c|}
\hline & & $\mathbf{N}$ & Mean & SD & SE & t-value & p-value \\
\hline & & 420 & 2.4 & 1.10 & \multirow{2}{*}{0.08} & \multirow{2}{*}{$14.23 *$} & \multirow{2}{*}{0.000} \\
\hline & & 420 & 3.5 & 1.14 & & & \\
\hline Key: & \multicolumn{3}{|c|}{$\begin{array}{l}N=\text { No. of Respondents } \\
S E=\text { Standard Error }\end{array}$} & & \multicolumn{3}{|c|}{$\begin{array}{l}S D=\text { Standard Deviation } \\
p=\text { probability }\end{array}$} \\
\hline
\end{tabular}

Table 16 illustrates that the calculated value of $t$ was found to be 14.23 which is statistically significant because it is greater than the table value of $t$ at 0.05 level. The mean score values indicate that whiteboards were used in private institutions but not used in public institutions.

Table 17: Responses of the respondents about the use of DVD Players

\begin{tabular}{|c|c|c|c|c|c|c|c|}
\hline & & $\mathbf{N}$ & Mean & SD & SE & t-value & p-value \\
\hline & & 420 & 2.2 & 0.75 & \multirow{2}{*}{0.07} & \multirow{2}{*}{1.51} & \multirow{2}{*}{0.131} \\
\hline & & 420 & 2.3 & 1.13 & & & \\
\hline Key: & \multicolumn{3}{|c|}{$\begin{array}{l}N=\text { No. of Respondents } \\
\boldsymbol{S E}=\text { Standard Error }\end{array}$} & & \multicolumn{3}{|c|}{$\begin{array}{l}S D=\text { Standard Deviation } \\
p=\text { probability }\end{array}$} \\
\hline
\end{tabular}

Table 17 indicates that the calculated value of $t$ was found to be 1.51 which is statistically non-significant because it is less than the table value of $t$ at 0.05 level. The mean score values show that DVD players were not used in both private and public institutions.

Table 18: Responses of the respondents about the use of Charts

$\begin{array}{llllll}\text { Institutions } & \text { N } & \text { Mean } & \text { SD } & \text { SE } & \text { t-value }\end{array}$




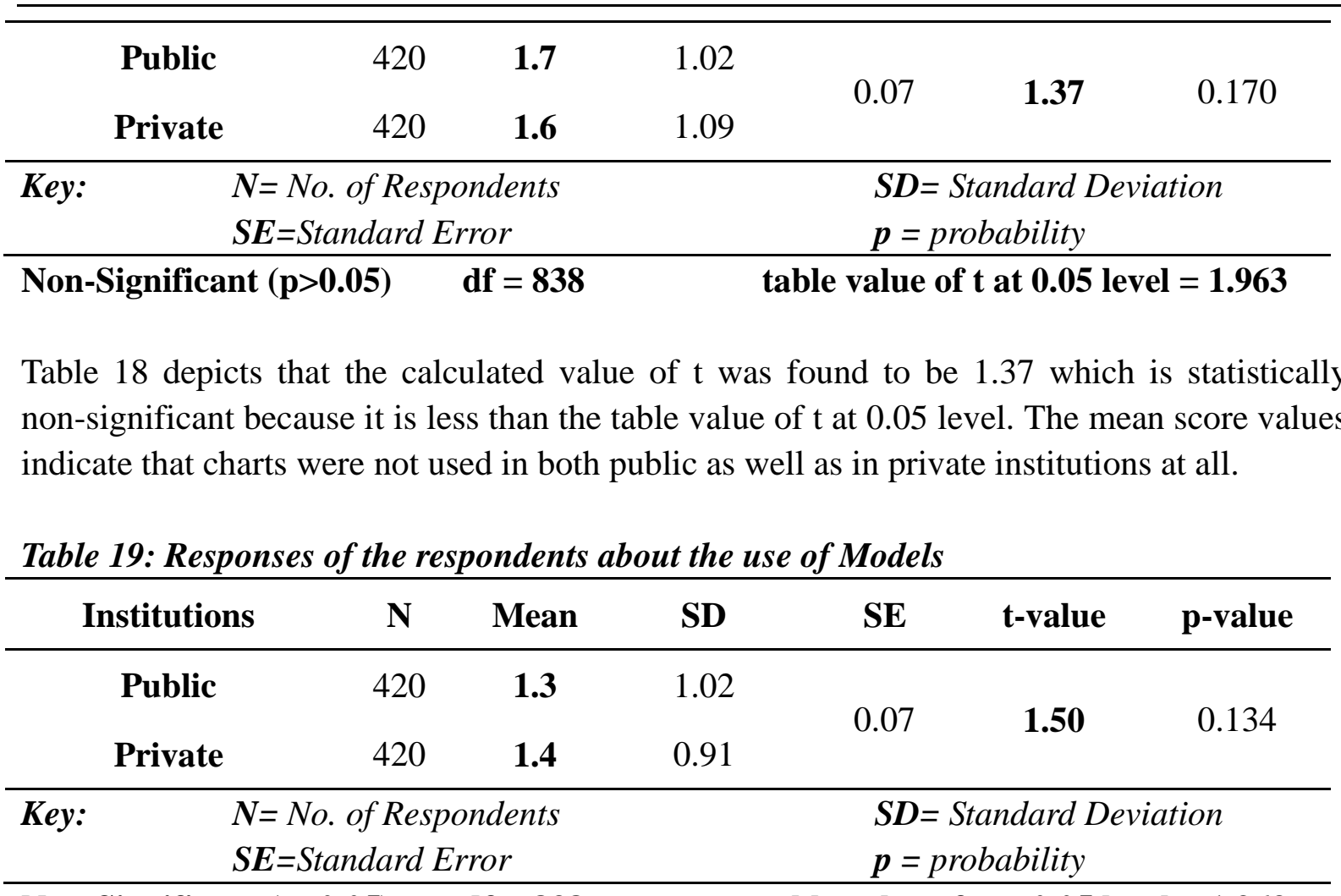

Non-Significant $(p>0.05) \quad$ df $=838$ table value of $t$ at 0.05 level $=1.963$

Table 19 reflects that the calculated value of $t$ was found to be 1.50 which is statistically non-significant because it is greater than the table value of $t$ at 0.05 level. The mean score values show that models were not used in both public as well as in private institutions at all.

Table 20: Responses of the respondents about the use of Educational Software and Videos

\begin{tabular}{ccccccc}
\hline Institutions & N & Mean & SD & SE & t-value & p-value \\
\hline Public & 420 & $\mathbf{1 . 6}$ & 0.92 & & & \\
Private & 420 & $\mathbf{1 . 7}$ & 0.96 & 0.06 & $\mathbf{1 . 5 4}$ & 0.124 \\
\hline
\end{tabular}

Key: $\quad$ No No. of Respondents

$\mathbf{S D}=$ Standard Deviation

$\mathbf{S E}=$ Standard Error

$\boldsymbol{p}=$ probability

Non-Significant $(p>0.05) \quad$ df $=838$

table value of $t$ at 0.05 level $=\mathbf{1 . 9 6 3}$

Table 20 shows that the calculated value of $\mathrm{t}$ was found to be 1.54 which is statistically non-significant because it is less than the table value of $t$ at 0.05 level. The mean score values show that educational software and videos are not used in both public and private institutions.

Analysis of the Usefulness of Educational Technology at Secondary Level

Table 21: Educational Technologies increase students'attention. 


\begin{tabular}{ccccccc}
\hline Institutions & N & Mean & SD & SE & t-value & p-value \\
\hline Public & 420 & $\mathbf{4 . 7}$ & 0.65 & & & \\
Private & 420 & $\mathbf{4 . 3}$ & 0.86 & & & \\
\hline
\end{tabular}

Key: $\quad$ N= No. of Respondents

$S D=$ Standard Deviation

SE=Standard Error

$\boldsymbol{p}=$ probability

*Significant $(\mathbf{p}<0.05) \quad$ df $=838$

table value of $t$ at 0.05 level $=\mathbf{1 . 9 6 3}$

Table 21 illustrates that the calculated value of $t$ was found to be 7.60 which is statistically significant because it is greater than the table value of $t$ at 0.05 level. The mean score values indicate that the respondents of the both sectors strongly agreed that educational technologies increase student's attention.

Table 22: Educational Technologies improve communication between teachers and students.

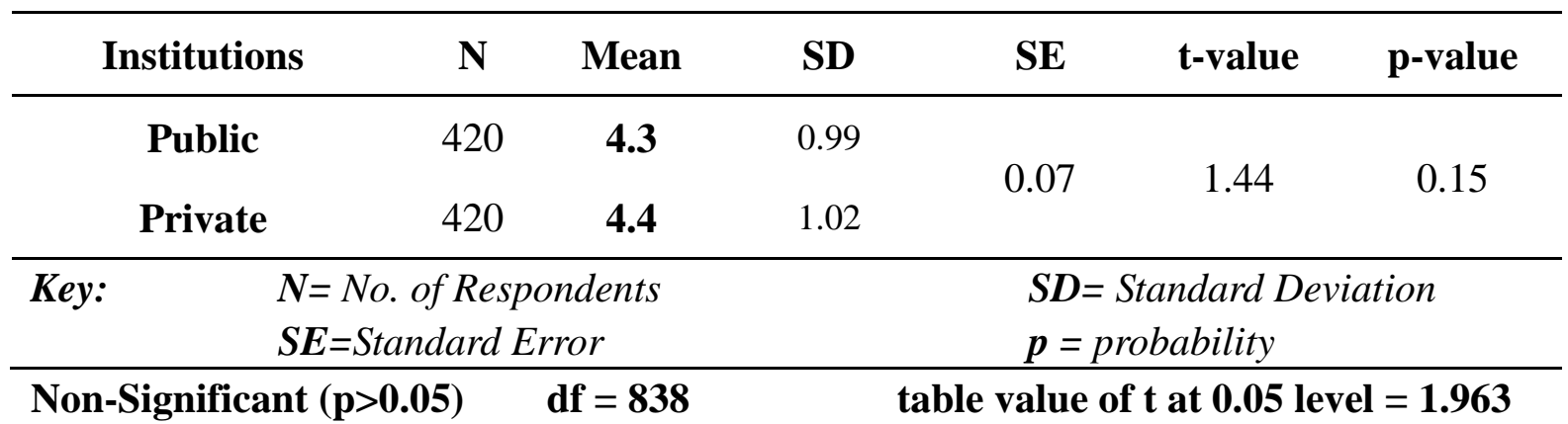

Table 22 depicts that the calculated value of $t$ was found to be 1.44 which is statistically non-significant because it is less than the table value of $t$ at 0.05 level. The mean score values indicate that the subjects of both sectors strongly agreed that educational technologies improve communication between teachers and students.

Table 23: Educational Technologies make complicated things easy and understandable.

\begin{tabular}{ccccccc}
\hline Institutions & N & Mean & SD & SE & t-value & p-value \\
\hline Public & 420 & $\mathbf{4 . 2}$ & 0.75 & & & \\
Private & 420 & $\mathbf{4 . 3}$ & 0.82 & 0.05 & 1.84 & $\mathbf{0 . 0 6 6}$
\end{tabular}

Key: $\quad$ No No. of Respondents

$S D=$ Standard Deviation

$\mathbf{S E}=$ Standard Error

$\boldsymbol{p}=$ probability

Non-Significant $(p>0.05) \quad$ df $=838$

table value of $t$ at 0.05 level $=\mathbf{1 . 9 6 3}$

Table 23 indicates that the calculated value of $t$ was found to be 1.84 which is statistically non-significant because it is less than the table value of $t$ at 0.05 level. The mean score values indicate that the respondents of both sectors strongly agreed that educational technologies make complicated things easy and understandable. 
Table 24: Educational Technologies make sure the students' participation in the classroom.

\begin{tabular}{ccccccc}
\hline Institutions & N & Mean & SD & SE & t-value & p-value \\
\hline Public & 420 & $\mathbf{4 . 6}$ & 0.88 & & & \\
Private & 420 & $\mathbf{4 . 7}$ & 0.94 & 0.06 & $\mathbf{1 . 5 9}$ & 0.11 \\
\hline
\end{tabular}

Key: $\quad$ N= No. of Respondents

$S D=$ Standard Deviation

SE $=$ Standard Error

$\boldsymbol{p}=$ probability

Non-Significant $(p>0.05) \quad$ df $=838$

table value of $t$ at 0.05 level $=\mathbf{1 . 9 6 3}$

Table 24 reflects that the calculated value of $t$ was found to be 1.59 which is statistically non-significant because it is less than the table value of $t$ at 0.05 level. The mean score values show that the respondents of both sectors strongly agreed that educational technologies ensure the students participation in the classroom.

Table 25: Learning environment becomes effective by the application of educational technologies for the instructional process.

\begin{tabular}{ccccccc}
\hline Institutions & N & Mean & SD & SE & t-value & p-value \\
\hline Public & 420 & $\mathbf{4 . 5}$ & 0.84 & & & \\
Private & 420 & $\mathbf{4 . 2}$ & 0.86 & 0.06 & $\mathbf{5 . 1 1 *}$ & 0.000 \\
\hline
\end{tabular}

Key: $\quad$ No No. of Respondents $\quad S D=$ Standard Deviation

$\boldsymbol{S E}=$ Standard Error $\quad \boldsymbol{p}=$ probability

*Significant $(\mathrm{p}<0.05) \quad \mathrm{df}=838 \quad$ table value of $t$ at 0.05 level $=\mathbf{1 . 9 6 3}$

Table 25 illustrates that the calculated value of $\mathrm{t}$ was found to be 5.11 which is statistically significant because it is greater than the table value of $t$ at 0.05 level. The mean score values indicate that respondents of public sector were more strongly agreed as compared to the respondents of private sector that learning environment becomes effective by the application of educational technologies for the instructional process.

Table 26: Teaching is more systematic by the use of educational technologies and much time can be saved with the help of educational technologies.

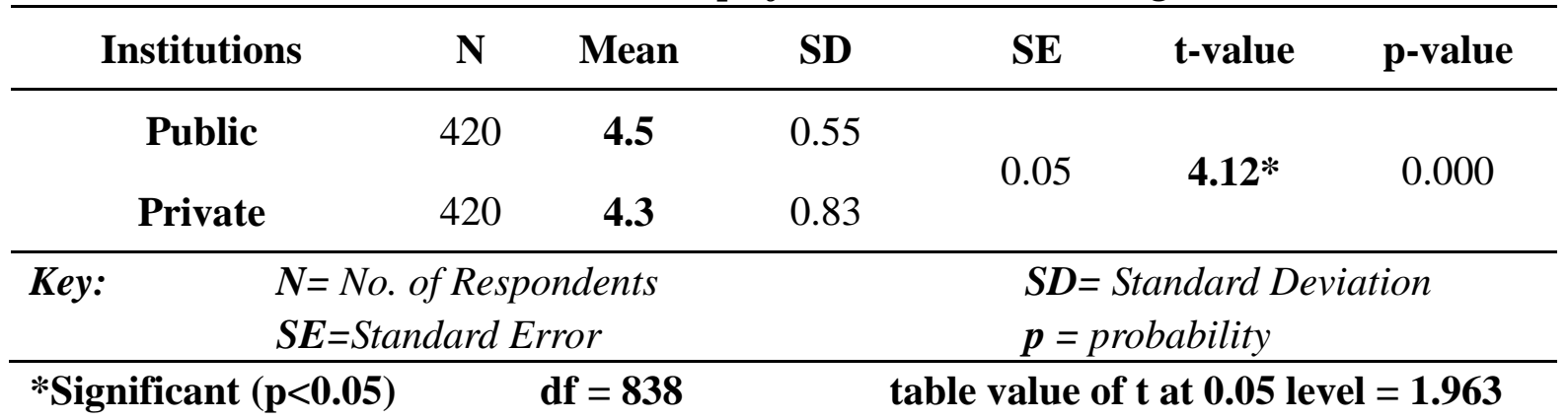




\section{Macrothink}

International Journal of Learning \& Development

ISSN 2164-4063

2012, Vol. 2, No. 5

Table 26 shows that the calculated value of $\mathrm{t}$ was found to be 4.12 which is statistically significant because it is greater than the table value of $t$ at 0.05 level. The mean score values show that respondents of public sector were more strongly agreed as compared to the respondents of private sector that teaching is more systematic by the use of educational technologies and much time can be saved with the help of educational technologies.

\section{Findings}

\section{Findings Regarding Availability of Educational Technology}

1. In majority of the institutions both in private as well as in public institutions, educational technologies were not available. Multimedia, educational television, models, radios, overhead projector and DVD players were not available in both public and private institutions.

2. Computers, educational software and videos were found to some extent in private institutions. On the other hand, in public institutions, only charts were found to some extent.

3. In majority of the private institutions whiteboards were found available but these whiteboards were not available in public institutions.

\section{Findings Regarding Usability of Educational Technology}

It was found that

1. Multimedia, overhead projectors, educational televisions, educational software, videos, radios, charts, models, DVD players were not used in both private as well as in public institutions.

2. Computers and whiteboards were used in private institutions to some extent. On the other hand these were not used in public institutions at all.

\section{Findings Regarding Usefulness of Educational Technology}

Majority of the respondents responded that

1. Educational technology increases students' attention.

2. It improves communication between teachers and students.

3. It makes complicated things easy and understandable.

4. It ensures the students' participation in the classroom.

5. Learning environment becomes effective by the application of educational technologies for instructional process.

6. Teaching is more systematic by the use of educational technologies and much time can be saved with the help of educational technologies.

\section{Conclusions}

In the light of findings, it is concluded that educational technologies i.e., multimedia, educational television, models, radios, overhead projector and DVD players were not available in both public as well as in private institutions. Only whiteboards, computers and educational software were found in private sector. In public sector, only charts were found 
available. But unfortunately, these available technologies were not used in both sectors. In addition, it was come to know that educational technology play an important role in both sectors. It improves the achievement level of the students in both sectors.

\section{Recommendations}

In the light of findings and conclusions, the following recommendations were made:

1. Availability of educational technology should be ensured in both public and private institutions. The owners of the private institutions should be bound by the government to ensure the availability of educational technology.

2. Computers, radios, educational television, multimedia, overhead projectors, models, videos, educational software, pictures, flip charts, charts, diagrams, film strips, educational software, whiteboards etc should be provided to public institutions on the emergency basis. Similarly, the owners of the private institutions should also ensure the availability of these technologies.

3. Teachers serving in private institutions should be provided sound and facilitated environment for the effective integration of educational technology.

4. A special formal training programme should be introduced for the effective use of educational technology.

5. All the in-service teachers serving in public and private institutions should be provided training opportunities for refresher courses to make them competent in using educational technology.

6. A compulsory subject regarding the preparation or utilization of educational technology should be introduced in teacher training programmes at each level.

7. All the public institutions should be provided special budget by the Government for purchasing new educational technologies according to the need and demand.

8. Alternate power supply should be provided to each public and private institution for the successful integration of educational technologies. For this purpose, power generators should be provided to each institution on the emergency basis.

9. Physical and technical infrastructure should be designed in such a way that educational technologies may be used effectively.

10. Educational technologies may be utilized in an effective way. A special supervisory staff should be appointed by the government to examine the utilization of educational technologies by the teachers serving in private and public institutions.

\section{Recommendations for Future Research Studies}

1. It is recommended that this type of research study should be conducted in other districts and provinces of the country.

2. It is also recommended that this type of research study should be conducted at primary, higher secondary and tertiary levels.

\section{References}

AECT, (1977). Task Force. Educational Technology. Definition and Glossary of Terms. Association of Educational Communication and Technology. Washington. p.23 
Aggarwal, J. C. (1995). Essential of Educational Technology Teaching Learning. India, Vishal Printers, Delhi. p. 33-34

Byard, M.J. (1995). Information technology under school-based policies for initial teacher training. Journal of Computer Assisted Learning, Vol. 11, 128-140.

Galbraith, J.K. (1967). The New Industrial State. Boson, MA: Houghton Mifflin. p.12

Hope, C. W. (1997). Why technology has not realized its potential in Schools: A perspective. American Secondary Education.

Jauszewski, A. (2006). Definition and Terminology Committee. TechTrends, 50(1), 10.

Mohanty, J. (1992). Educational Technology. Deep and Deep publications. New Delhi. p.5

Mumtaz, S. (2000). Factors Affecting Teachers' Use of Information and Communication Technology: A review of the Literature. Journal of Information Technology for Teacher Education, 9(3), 319-342.

Ringstaff, C. \& Kelley, L. (2002). The Learning Return on Our Educational Technology Investment. A Review of findings from Research. WestEd RTEC, 730 Harrison Street San Francisco, CA 94107-1242.

Roblyer, M.D., \& Edwards, J. (2000). Integrating Educational Technology into Teaching. Prentice Hall, Inc., Pearson Education. Upper Saddle River, New Jersey, Columbus, Ohio. P.6

Sharma, Y.K \& Sharma, M. (2006). Educational Technology and Management. Kanishka Publishers, Distributors, New Delhi-110 002. Vol-1. p.28,31, 41, 57-58

Smarkola, C (2008). Efficacy of a planned behavior model: Beliefs that contribute to computer usage intentions of students teachers and experienced teachers. Computer in Human Behavior, 24(3), 1196-1215.

Suleman, Q. (2001). Role of Educational Technology at Primary School Level in District Karak (Khyber Pukhtunkhwa) Pakistan. International Journal of Academic Research in Business and Social Sciences, 1(3), 85-95.

Tomei, L.A. (2002). The Technology Façade: Overcoming barriers to effective instructional technology. San Francisco: Allyn \& Bacon.

Veen, W. (1993). The role of beliefs in the use of information technology: Implications for teacher education, or teaching the right thing at the right time. Journal of Information Technology for Teacher Education, Vol.2, 139-153.

Venkataiah, N. (1996). Educational Technology. APH Publishing Corporation. 5, Ansari Road, Daryagang, New Delhi-110002.

Wikipedia Free Online Encyclopedia. Educational Technology. http://en.wikipedia.org/wiki/Educational_technology

Wild, M. (1996). Technology refusal: Rationalizing the failure of students and beginning teachers to sue computers. British Journal of Educational Technology, Vol. 27, 134-143. 